
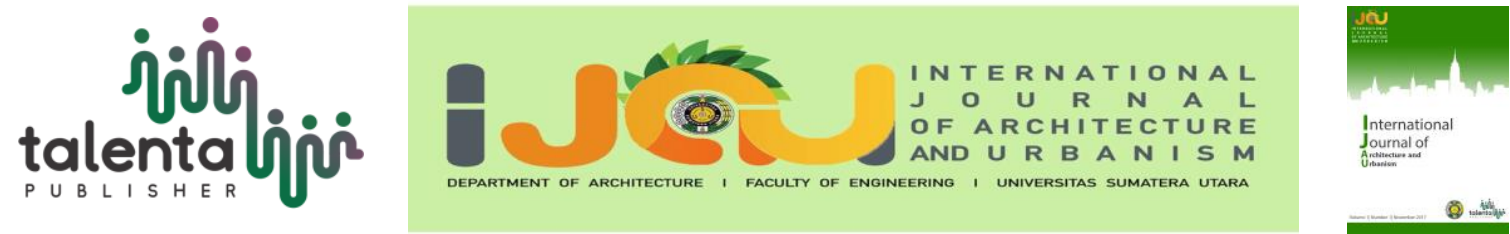

\title{
Evaluation of Fire Protection Systems in Hotel Building (Case Study: Grand Kanaya Hotel Medan)
}

\author{
Iras Muthiah Hanan ${ }^{*}$, Basaria Talarosha ${ }^{1}$ \\ ${ }^{1}$ Architecture Department, Faculty of Engineering, Universitas Sumatera Utara, Medan, Indonesia.
}

\begin{abstract}
Hotel is a public living facility for tourists by providing room services, food and beverage providers, and accommodation with payment terms. Fire is a flame, both small and large, which is usually hard to control and detrimental and can occur in a place that we do not expect. Ensuring the protection of hotel residents is one of the goals of hotel business standards. Grand Kanaya Hotel is a 3-star hotel building in the city of Medan, with 152 units of rooms and several facilities that enable activities involving large numbers of people, such as restaurants and ballrooms. According to the quite high number of occupants, Grand Kanaya Hotel requires a fire protection system that can protect all hotel residents against fire hazards. The study aims to evaluate the fire protection system that has been applied to the building of the Grand Kanaya Hotel and provide references for fire protection systems that are standard in hotel buildings. This research is using the qualitative method that obtains from field observation and uses a type of descriptive research that explains the facts or existing conditions of fire protection systems in the Grand Kanaya Hotel building. The results show that there are several fire protection systems in Grand Kanaya Hotels that not according to the standards, such as the minimum size, the material used is not resistant to fire, and maximum distance lies, which still exceeds the maximum value. The study results are useful as information for other researchers and hotels regarding fire protection systems at the Grand Kanaya Hotel building.
\end{abstract}

Keywords: fire, hotel, protection, system.

\section{Introduction}

Every building has a risk of fire, as with a hotel building. In 2009, the hotel fires happened at the M-City Hotel, which recorded 20 deaths with burnt and smoke poisoning due to being trapped in the building. A lack of rescue facilities and the absence of warning alarms or notification of fires caused deaths. Grand Kanaya Hotel is a 3-star hotel consisting of 152 rooms and several facilities such as restaurants and ballrooms. As required by Ministry of Public Works Regulation No.26/Prt/M/2008 concerning Technical Requirements for Fire Protection Systems in Building and Environment Buildings [1], Grand Kanaya Hotels are

\footnotetext{
*Corresponding author at: Department of Architecture, Faculty of Engineering, Universitas Sumatera Utara, Jalan Perpustakaan Gedung J07, Medan 20155, Indonesia

E-mail address: irasmhanan@gmail.com
} 
required to implement active and passive protection systems that comply with fire protection system standards that can be adequate or help all residents to evacuate to a safe place.

\section{Literature Review}

Fire is a flame, whether small or large, which is generally difficult to control and is detrimental, can occur in a place that we do not expect [2]. Fires will ensue if the flammable material, oxygen, and also heat continues to be maintained as a chain reaction and causes continuous combustion.

Fires can occur anywhere, including hotel buildings. Hotels are public residence facilities for tourists that provide room services, food, and beverage providers, and accommodation with payment terms [3]. According to the Head of Labor Ministry No186/MEN/1999, the hotel building is in the classification of buildings with minor fire hazards. The hotel building is a building that has many users and activities; therefore, to protect all residents from fire hazards, hotel buildings are required to have a fire protection system that meets standards.

Fire protection system according to the Ministry of PUPR of the Republic of Indonesia in Regulation of Ministry of Public Works No.26/PRT/M/2008 is a system consisting of equipment, completeness, and facilities, both installed and built-in buildings that are used both for active protection systems, passive protection systems, and management methods to protect buildings and the environment against fire hazards. According to Egan (1978), in the book "Concepts in Building Fire Safety," protection against fires in buildings is intended so that occupants of buildings affected by the fire can save themselves safely [4].

The fire protection system consists of an active fire protection system and a passive fire protection system. Both protection active and passive are needed simultaneously in the event of a fire, while the active protection system works to notify hotspots and extinguish fires directly with protection devices, passive protection systems refer to architectural design and design structures that are stable and have fire resistance and can inhibit fire/heat transmission and design access roads which is used to help residents get out of the building safely.

The active fire protection system is a system through existing facilities contained in buildings or protection systems by handling fire/fire directly [4]. Based on different sources, an active fire protection system is a complete fire protection system consisting of both manual and automatic fire detection systems, water-based fire extinguishing systems such as sprinklers, standpipes, and fire hosen, a chemical-based fire extinguishing system, such as APAR and special extinguishers [1]. 
Sprinkler installation is a fire extinguisher installation system that is installed permanently in a building that can extinguish fires automatically by spraying water in the place where the fire first occurs (SNI 03-3989-2000). For all high-rise buildings, except where guest rooms or suite guest rooms that have the same exit access as the exterior access road must have the sprinkler system as protection. The maximum distance between the sprinkler heads in one row and the maximum distance between adjacent rows is $4.6 \mathrm{~m}$.

The fire alarm system is an automatic

fire detection system by looking at changes that occur in the surrounding environment related to a fire. Each floor must provide the manual call point box with the horizontal distance that must be taken to reach a manual call point box on the floor not to exceed $60 \mathrm{~m}$.

The heat detector function is to detect a drastic increase in room temperature in a room. Location requirements and placement of heat detectors according to SNI 03-3985-2000, among others, point type detectors must be placed on the ceiling with a distance of not less than $100 \mathrm{~mm}$ (4 inches) from the side of the wall and each detector placed at a distance equal to 0,7 times the registered distance (the distance between detectors is $9.1 \mathrm{~m}$ ). On a ceiling with a height of about $3 \mathrm{~m}(10 \mathrm{ft})$ to $9 \mathrm{~m}(30 \mathrm{ft})$, the distance between the heat detectors must follow to table 1 .

Table 1. Correction for high ceilings

\begin{tabular}{cc}
\hline Ceiling Height $(\mathrm{m})$ & $\begin{array}{c}\text { Percent of the listed } \\
\text { distance }\end{array}$ \\
\hline $0-3,0$ & 100 \\
\hline $3,0-3,6$ & 91 \\
\hline $3,6-4,2$ & 84 \\
\hline $4,2-4,8$ & 77 \\
\hline $4,8-5,4$ & 71 \\
\hline $5,4-6,0$ & 6,0 \\
\hline $6,0-6,7$ & 58 \\
\hline $6,7-7,3$ & 52 \\
\hline $7,3-7,9$ & 46 \\
\hline $7,9-8,5$ & 40 \\
\hline $8,5-9,1$ & 34 \\
\hline
\end{tabular}

Regarding the Ministry of Manpower and Transmigration Regulation No. 04 1980, fire extinguishers are lightweight and easy to use by one person to extinguish fires at the beginning of a fire. Based on Permenaker No. 04 of 1980, fire extinguishers should be red, placed in a position that is easily seen clearly and easily accessible, hanging on the wall so that the top is at an altitude of $1.2 \mathrm{~m}$ from the floor surface. Placement between fire extinguishers must not exceed 15 meters and not places in a room or place where the temperature exceeds $49^{\circ} \mathrm{C}$ or drops to minus $44^{\circ} \mathrm{C}$. 
The building fire hydrant is a fire prevention system that uses water supply in buildings. Based on Pd-T-11-2005-C, hose and hydrant boxes should not be blocked and must be located not more than $1.5 \mathrm{~m}$ ( 5 feet) above the floor surface or less than $0.9 \mathrm{~m}$ ( 3 feet), having a box for storing and a $35 \mathrm{~mm}$ diameter hose connection in excellent condition with a minimum hose length of $30 \mathrm{~m}$ and an adequate water supply for the system needs for at least 45 minutes.

The placement of exit sign or pointing arrows is at the intersection of the corridor, way out to the emergency staircase, balcony or terrace, and the door to the emergency stairs. The direction sign says "EXIT" or other suitable words, with letters that are easy to see, the minimum height of $15 \mathrm{~cm}$, and the letter thickness of at least $2 \mathrm{~cm}$. The word "EXIT" must have a letter width of at least $5 \mathrm{~cm}$ except for the letter "I" and the minimum distance between minimum letters of 1 $\mathrm{cm}$; a more significant direction signs are according to the proportional size to their height (Figure 1).

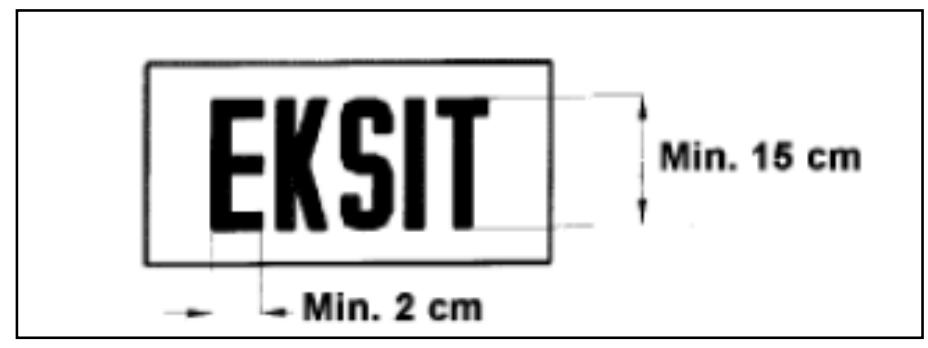

Figure 1. Signboard Standard

(Source: SNI 03-6574-2001)

The technical requirements, according to SNI 03-6574-2001, are that each emergency lamp must work automatically and have a sufficient level of lighting for safe evacuation (minimum of 10 lux from the floor). In a centralized system, one backup power and automatic control must have protection from damage due to fire with a cover construction that has a fireresistance level not less than 1 hour.

Passive fire protection systems are fire protection systems that are formed or built through regulation of building structures, compartmentalization, or separation of buildings based on fire resistance levels, as well as protection against openings [1]. The passive protection system refers to the architectural design and designing a stable structure and has fire resistance and can inhibit fire/heat propagation and design access exits that are used to help residents safely escape the building. A passive fire protection system consists of completeness on the site and escape tool.

Site planning is planning that regulates the site to prevent and minimize fire hazards, which includes the layout and orientation of the building, the distance between buildings, the placement of yard hydrants, the provision of open spaces, and others [1]. Based on the 
Ministry of Public Works Decree No.10 / KPTS / 2000, components of site completeness consist of water sources, road environment, and the distance between buildings and yard hydrants.

Water sources are sources that provide a water supply as a medium for fire suppression in buildings. According to the Ministry of Public Works Decree No.02/KPTS/1985, environmental water sources can be in the form of water reservoirs/tanks for fires.

Road pavement must be available in the building environment so the firetrucks can traverse [1]. In every part of a building (other than class 1,2 , and 3 buildings), the pavement must be placed directly in the fire extinguisher access opening in buildings. The pavement layer must always be free of obstacles, made of metal, paving blocks, or reinforced layers to support the equipment load. Pavement must be made as flat as possible with a slope of not more than 1 : 15, and a maximum slope of 1: 8.5 for the inlet, pavement can accommodate the entrance and maneuver of fire engines, snorkels, car pumps and staircases and hydraulic platforms with minimum width 6 meters and a minimum length of 15 meters, and a minimum width of 4 meters in other parts of the entry point used for passing fire trucks.

A minimum distance between buildings must be determined to protect against the widespread fire. The minimum distance between buildings is not intended to determine the demarcation line of a building. Provisions on minimum distance according to the regulation of the Ministry of Public Works No.26 / PRT / M / 2008 [1] can be seen in table 2.

Table 2. The standard of inter-building distance.

\begin{tabular}{ccc}
\hline No. & Building height $(\mathrm{m})$ & $\begin{array}{l}\text { The minimum of inter- } \\
\text { building distances }(\mathrm{m})\end{array}$ \\
\hline 1 & $<8$ & 3 \\
\hline 2 & $<14$ & $<6$ \\
\hline 3 & $<40$ & $<8$ \\
\hline 4 & $>40$ & $>8$ \\
\hline & (Source: $[1])$
\end{tabular}

Yard hydrants are hydrants located outside buildings/buildings in locations that are safe from fire, and the distribution of fire supplies into buildings is carried out through the "Siamese" valve. Each part of the fire truck's access point on the building's land must be within $50 \mathrm{~m}$ of distance from the city hydrant. The buildings must provide the yard hydrant if the city hydrants are not available. In situations where more than 1-yard hydrant is needed, the hydrants are along with the access point of the fire engine until each part of the line is within a radius of 50 $\mathrm{m}$ from the fire hydrant. 
Evacuation route is a track as a direct and rapid transfer from people who will stay away from threats or events that endanger lives [5]. Components of exit facilities consist of corridors, emergency stairs, and emergency doors. According to the Fire Training Guide for Tk. 1 (2002), the evacuation route is a path that is unobstructed and must be able to be traversed by residents in the event of an emergency from each point of the building to a safer place. In hotel buildings, there are standards of comfort and corridor length. Based on the consideration of comfort in circulation, the maximum length of the corridor in the hotel is $30 \mathrm{~m}$ (without sprinkler) or $45 \mathrm{~m}$ (with a sprinkler) [5].

Fire escape staircase is a stair precisely planned for rescue in the event of fire [1]. Based on the Ministry of Public Works Regulation No. 45 / PRT / M / 2007, each state building with more than three floors must have a minimum of two emergency stairs with a maximum distance of 30 $\mathrm{m}$ (if using a sprinkler the distance can be 1.5 times, which is $45 \mathrm{~m}$ ). Emergency/rescue stairs should not be in the form of a vertical circular staircase with a maximum height of stairs is $19 \mathrm{~cm}$, and the width of the emergency stairs is a minimum of $110 \mathrm{~cm}$. The minimum room height is $200 \mathrm{~cm}$ and must be equipped with a fire-resistant door, a minimum of 2 hours.

Fire doors are doors that go directly to the fire stairs and only used when a fire occurs [1]. Each building with a level of more than three must have a minimum of 2 emergency doors with a maximum distance of 25 meters from each point of the position of people in one building block [6]. Emergency doors must be resistant of fire for at least 2 hours, equipped with an automatic cover, warning signs, painted in red and equipped with a minimum of three hinges and a fireresistant glass of at least $1 \mathrm{~m} 2$ and placed in the upper half of the door leaf.

\section{Methodology}

The research location is a 3-star hotel located on Jalan Darussalam No. 12, Medan, North Sumatra, Indonesia (Figure 2). Hotel Grand Kanaya is a 6-floor vertical residential building consisting of 152 rooms with additional facilities such as restaurants, lounges, souvenir shops, meeting rooms, and ballrooms. 


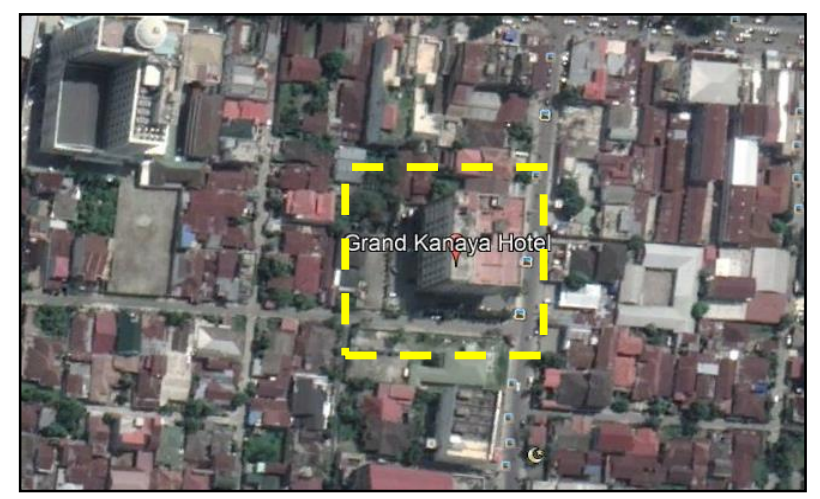

Figure 2. Location of the research area

(Source: http://earth.google.com/)

A descriptive study aims to obtain existing data from the fire protection system at Grand Kanaya Hotel. Research variables and indicators are from the results of the literature review that has been carried out. Based on this, it requires primary data obtained from field observations as well as secondary data in the form of information related to the location and various literature needed.

\section{Result and Discussion}

For active fire protection systems in Grand Kanaya Hotel buildings, each corridor has a sprinkler installation mounted on the ceiling on each floor of the building. The installation of the sprinkler system on the 1 st floor is with a height of $7 \mathrm{~m}$ from the floor, and the maximum distance between sprinklers reaches $17.4 \mathrm{~m}$. The sprinkler system on the 2 nd floor of the Grand Kanaya Hotel is a height of $5 \mathrm{~m}$, and the maximum distance between the sprinklers reached $17,4 \mathrm{~m}$. Sprinkler systems on floors 3-6 are also on the corridor ceiling with a height of 3,5m, and the maximum distance between sprinklers is $26,8 \mathrm{~m}$. Based on this, the sprinkler system at Grand Kanaya Hotel has not met the standards of the sprinkler system because the sprinkler distance available in buildings exceeds the standards in SNI 03-3989-2000, which is 4,6m (Figure 3). 


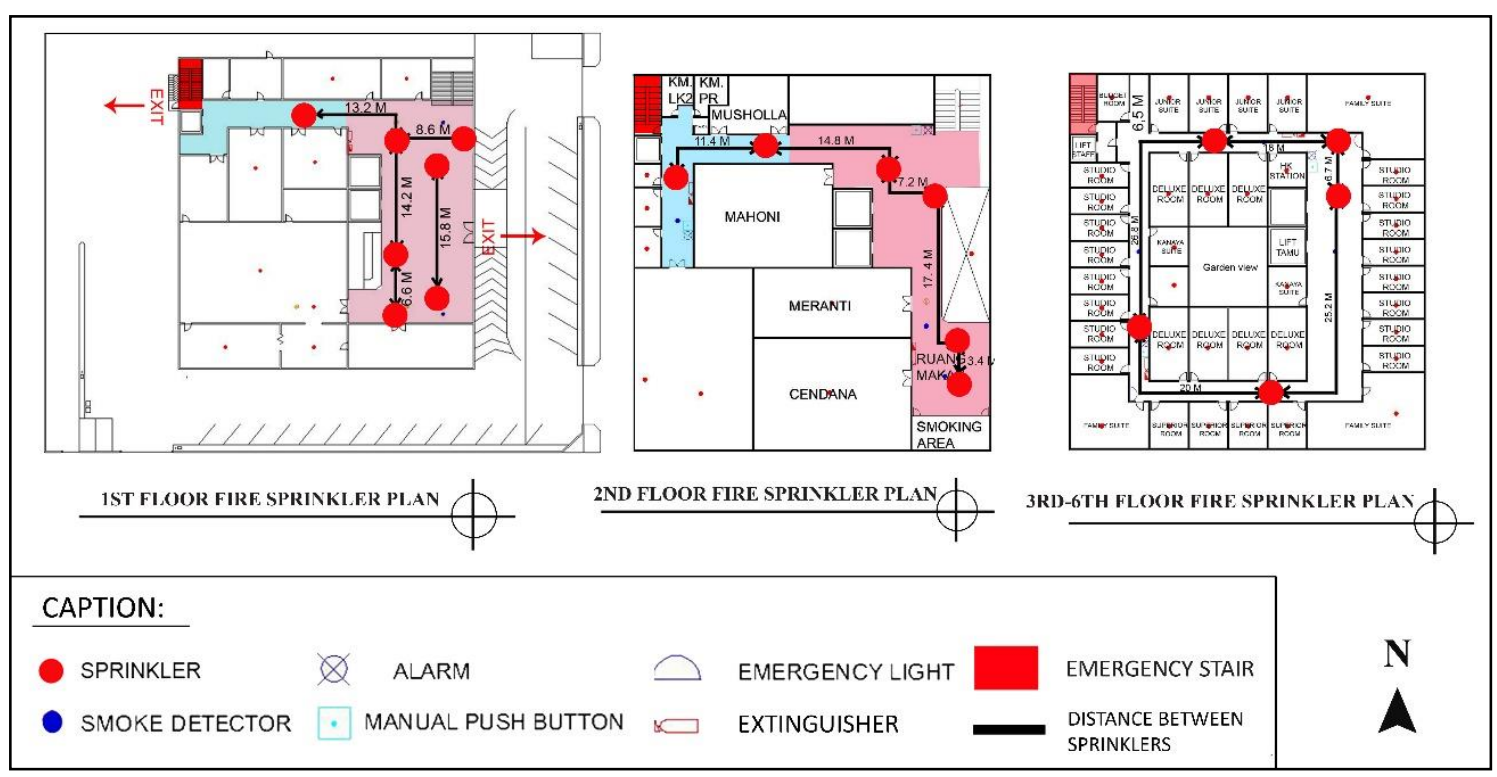

Figure 3. Analysis of the sprinkler system

On the 2nd to sixth floors of the Grand Canyon Hotel, there are fire alarm systems, but there is no fire alarm on the 1st floor. Each manual call point box on the building is easy to reach, unobstructed, and visible, placed at the farthest reaches distance of $34,4 \mathrm{~m}$. Therefore, the placement of fire alarms by the maximum distance is $60 \mathrm{~m}$ from each point on the floor. The distance between the fire alarm system is in Figure 4.

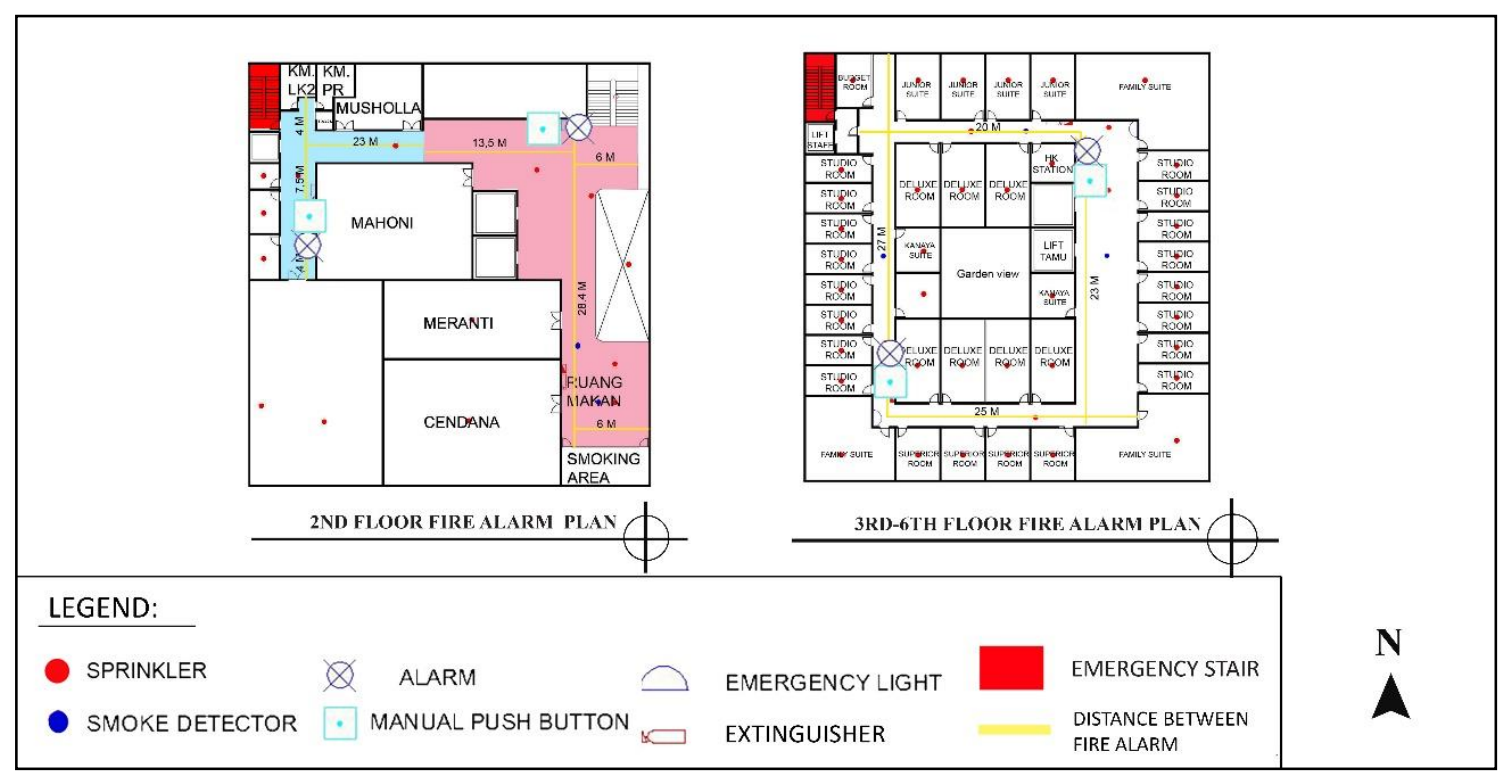

Figure 4. Analysis of fire alarm. 
Furthermore, smoke detectors are available on every floor of the building. The placement of the heat detector is on the ceiling with a distance of 0.6-1 $\mathrm{m}$ from the wall, which means it meets a minimum distance of $10 \mathrm{~mm}$. The distance of the heat detector on the 1 st floor between the detectors is reaching 22 meters, the detector on the 2 nd floor reaches 7 to $37 \mathrm{~m}$, and on the $3 \mathrm{rd}$ 6th floor, it reaches $18-27.8 \mathrm{~m}$. Based on the standard distance between detectors in table 2.3, the placement of a heat detector at Grand Kanaya Hotel is not suitable because it exceeds the standard installation distance between detectors. The distance between each smoke detector is in Figure 5.

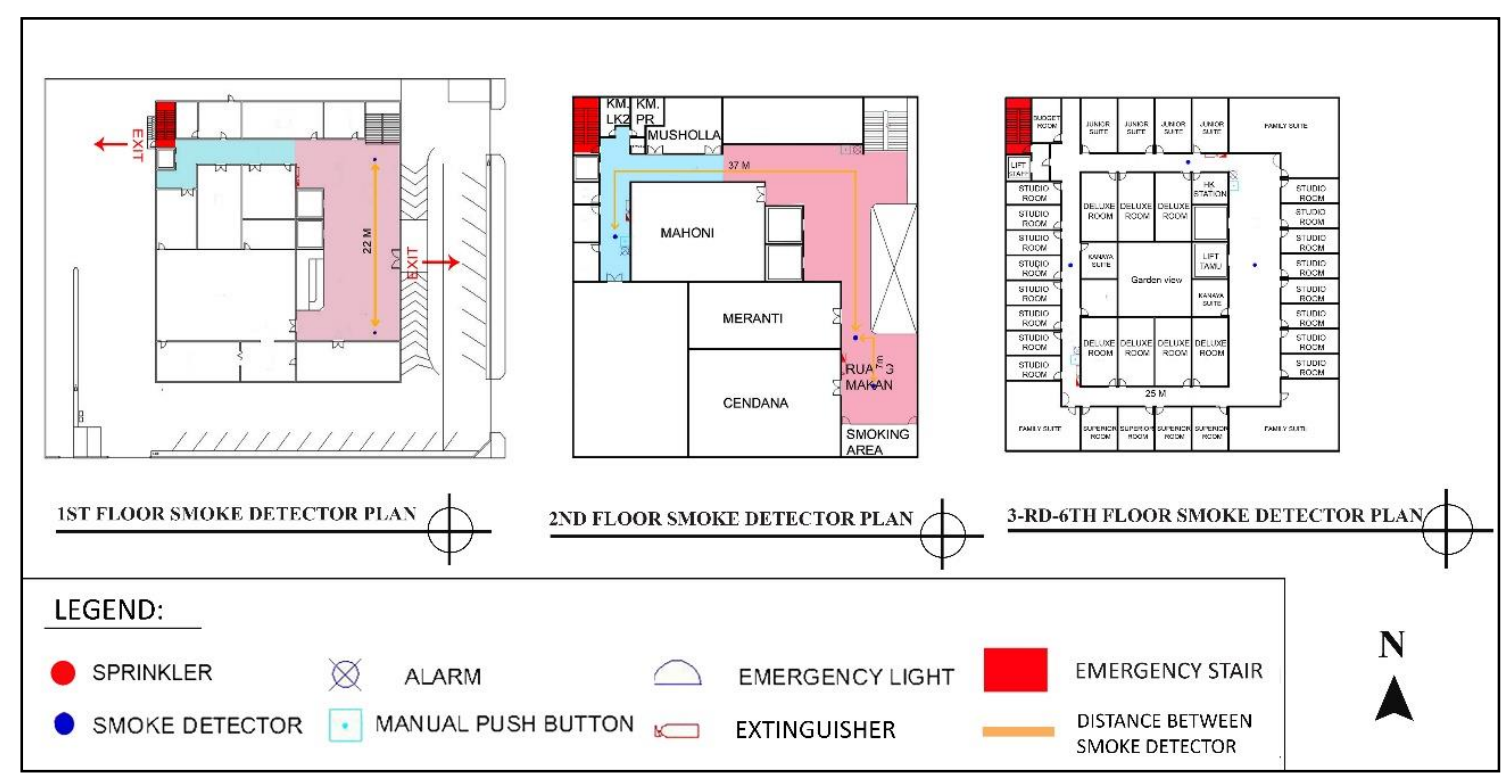

Figure 5. Analysis of Smoke Detector.

On the building's 1 st floor, there is one fire extinguisher, on the second floor there are 2 APAR with the distance between fire extinguisher reaching $47 \mathrm{~m}$ and on the 3-6 floors reaching $35 \mathrm{~m}$. The placement of fire extinguishers on each floor is contrary to the fire extinguisher placement standard in Permenaker No. 04 of 1980, which should not exceed 15m. Fire extinguishers at Grand Kanaya Hotel are placed in a place that does not have a temperature exceeding $49^{\circ} \mathrm{C}$ or down to minus $44^{\circ} \mathrm{C}$, easily seen clearly, and easily achieved (Figure 6). 


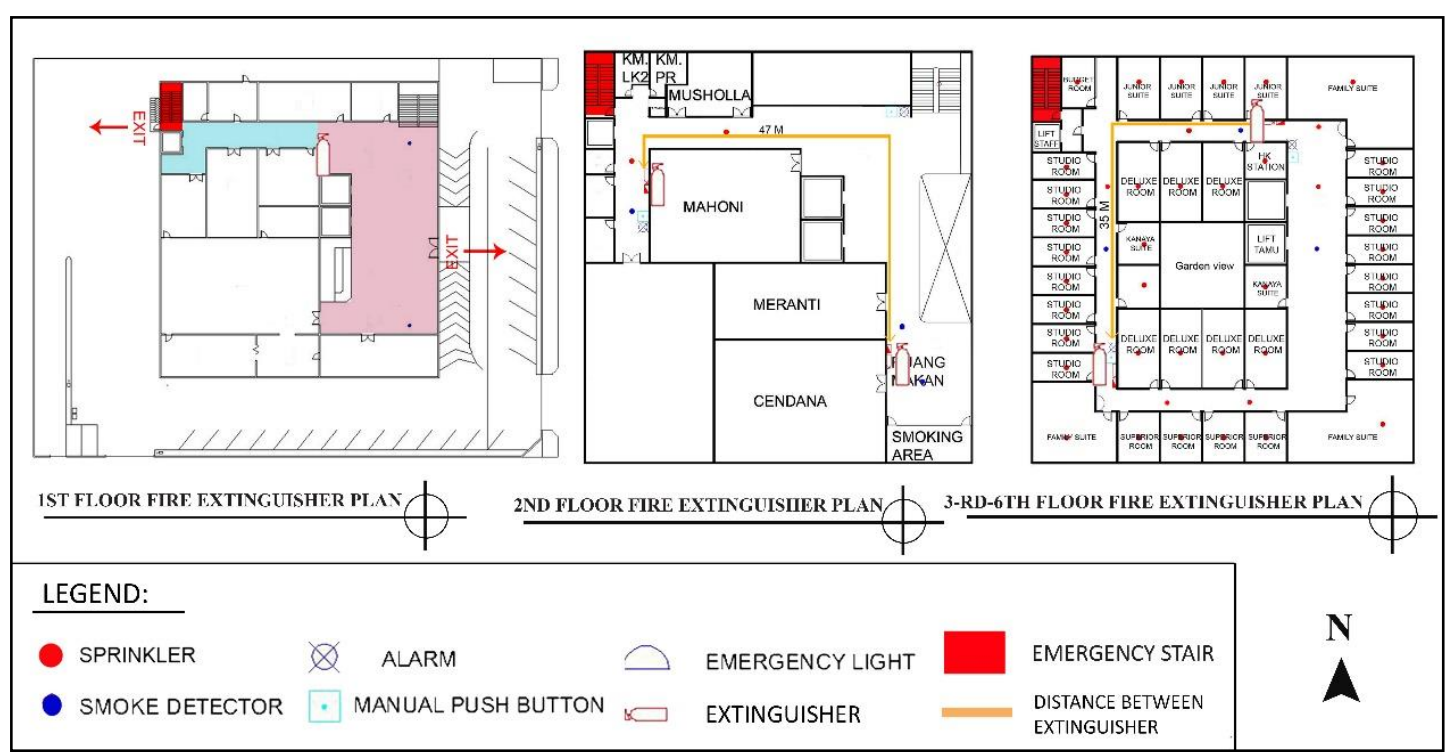

Figure 6. Analysis of Fire Extinguisher

Besides, Grand Kanaya Hotel also has building hydrants on each floor. The building hydrant consists of a fire hose, hose rack, and nozzle. The hydrant is attached to the wall using a standpipe. Hydrant hoses and boxes are not blocked and placed $1 \mathrm{~m}$ from the floor surface, which means the building hydrants meets the standard of building hydrants placement on Pd-T11-2005-C. Hydrant conditions are in figure 7.

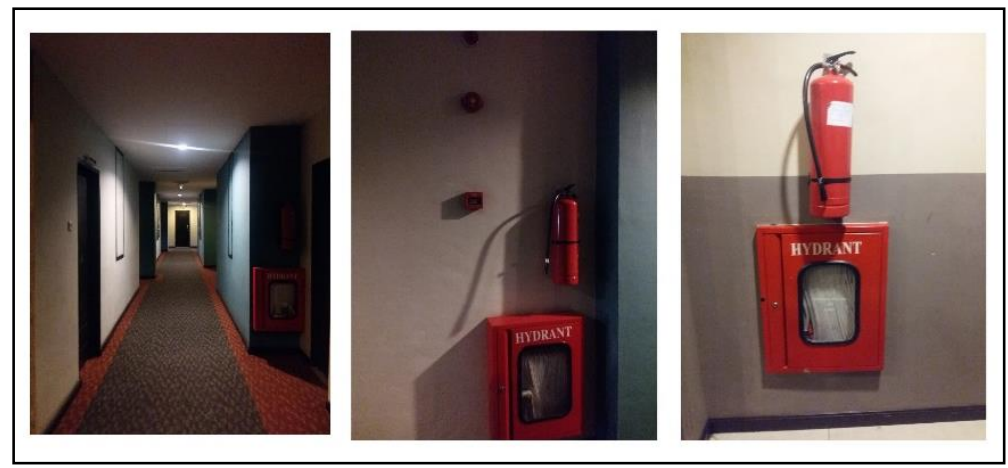

Figure 7. Conditions of Building Fire Hydrant

Signboards are available at each intersection of the exit, and above corridors, the sign of direction is also equipped with lighting to make it easy to see if there is a power outage during a fire. Emergency lighting is also available at each corridor intersection but is not available in the fire staircase. Based on this, the sign of direction at the Grand Kanaya Hotel has met the standard directional signs contained in SNI 03-6574-2001 concerning Procedures for Designing Emergency Lighting, Direction Marks, and Hazard Warning Systems on Buildings, but emergency lighting does not meet the requirements because not available on emergency stairwells. The conditions of direction signs and emergency lighting at the Grand Kanaya Hotel is in figures 8 and 9. 


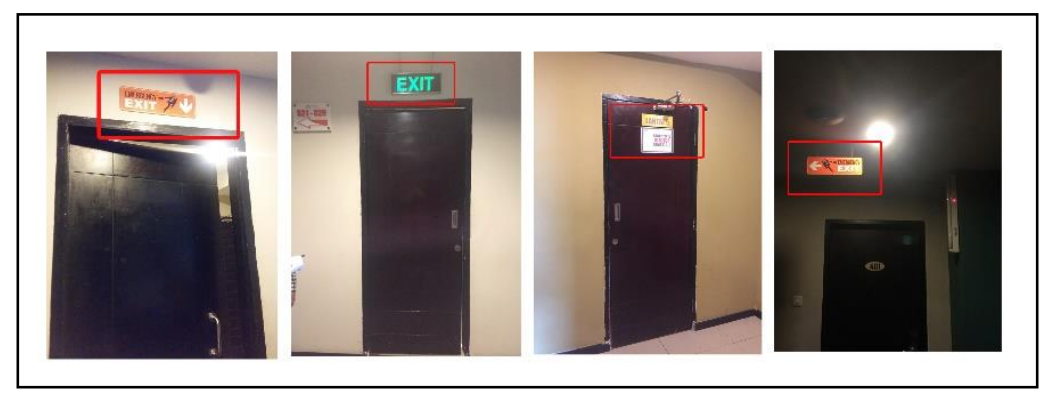

Figure 8. Conditions of Signboard

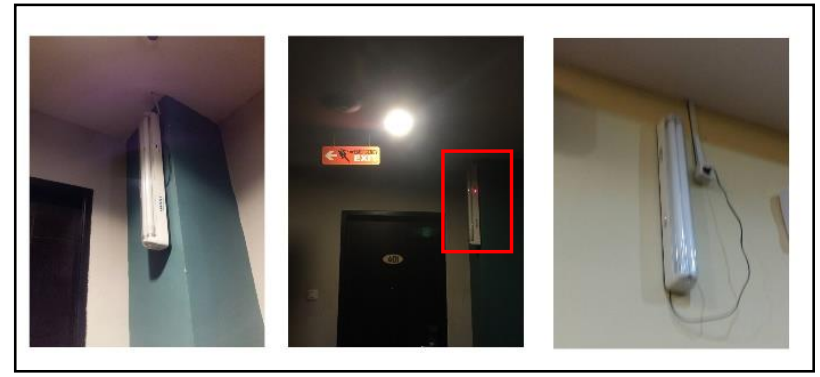

Figure 9. Conditions of Emergency Lighting

In addition to the active fire protection system, Grand Kanaya hotels also provide a passive fire protection system to help protect occupants during a fire. Grand Kanaya Hotel has a water source in the form of a tank on the underground surface that meets the water supply standards and can drain water for at least 45 minutes. Therefore, the water source in Grand Kanaya Hotel has met the standard in the Ministry of Public Works Decree No.02/ KPTS/1985.

Grand Kanaya Hotel does not have a specific pavement layer for fire engines. Access to the entrance of the fire engine must be in paving block material, which has a width of 6 meters and 7 meters at the exit, with a flat road surface, which is not following predetermined environmental road standards, because it does not have a particular pavement layer for fire engines.

The distance between the hotel and the buildings around has met the standard to protect against the fire widespread. The distance among the buildings is 21 meters in the east, 13 meters in the south, and 15 meters in the west. Whereas in the northern part of the building, the distance between the hotel building and the building next to it is 3 meters, it does not meet the minimum standards that have been determined, namely with a minimum distance of 6 meters (Figure 10). 


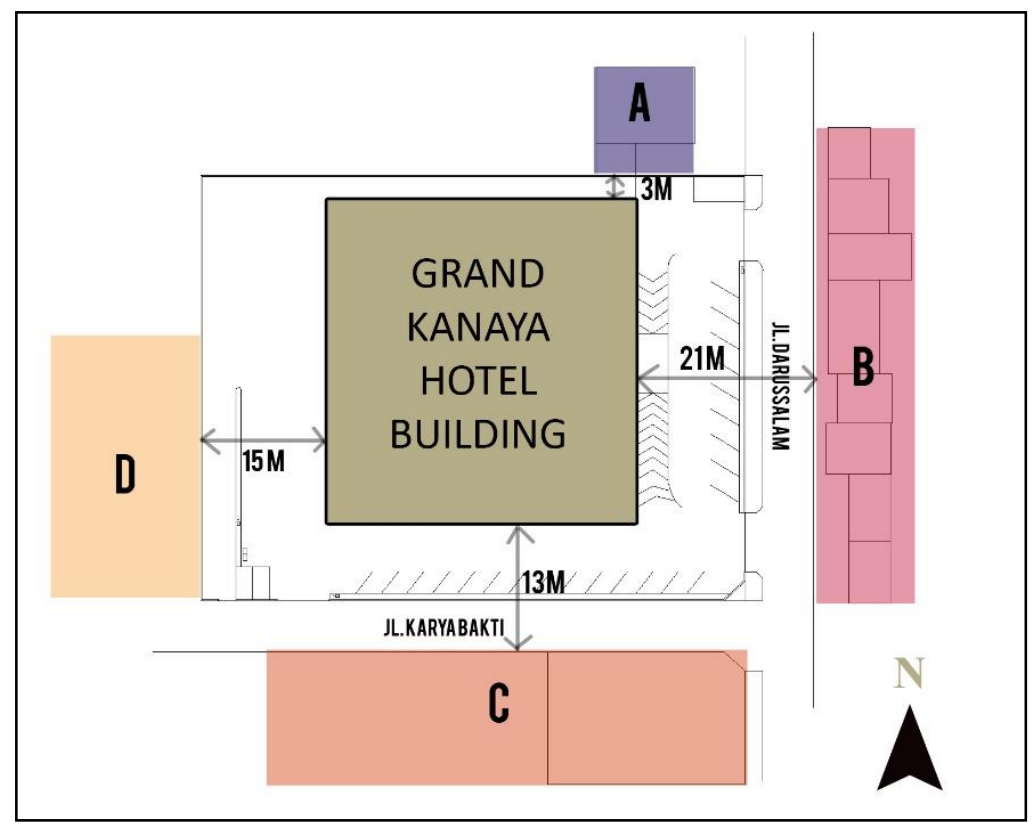

Figure 10. Inter-building Distance

On the outside of the Grand Kanaya Hotel building, there are no city hydrants, but Grand Kanaya Hotel has three pieces of yard hydrants along the fire engines access road with the farthest radius of $40 \mathrm{M}$ from each point in the area. Therefore, the yard hydrant on Grand Kanaya Hotel meets the standard of the yard fire hydrant on SNI 03-1735-2000, which is along with the access point of the fire engine in such a way which each part of the line is within a radius of $50 \mathrm{~m}$ from the hydrant (Figure 11).

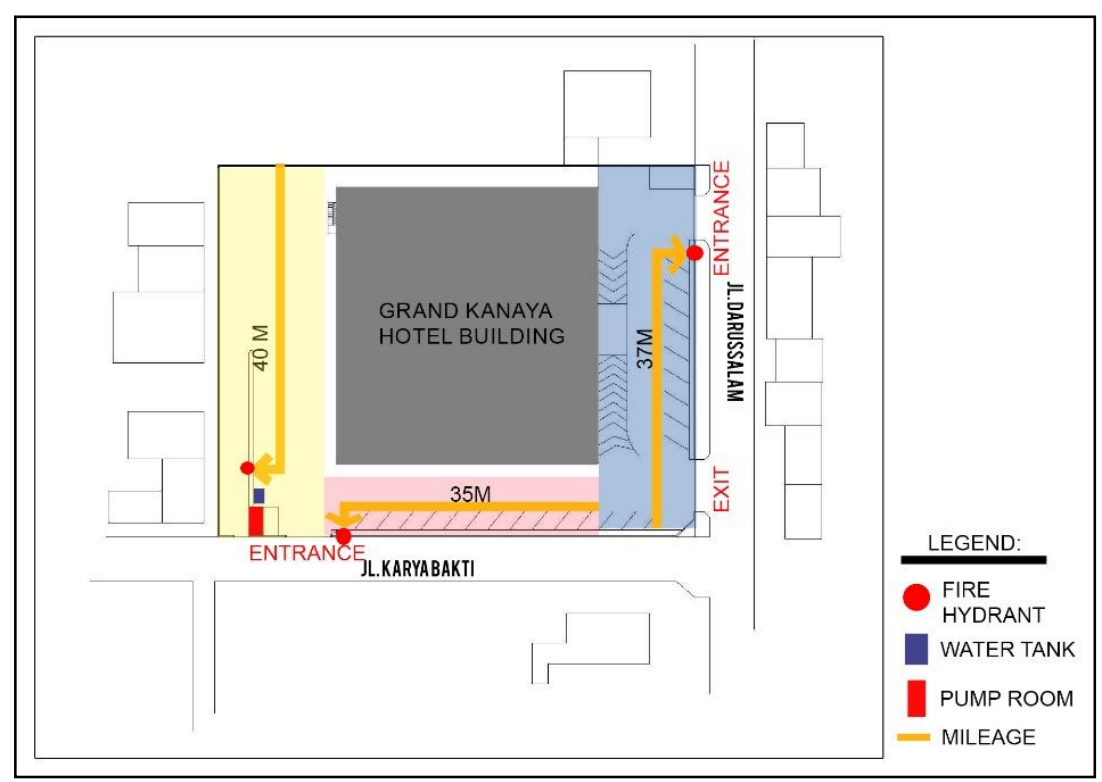

Figure 11. Yard Fire Hydrant

The interior corridor in the Grand Kanaya Hotel is the building circulation as a way out of buildings during an emergency. The corridors are free of obstacles to reducing the risk of accidents during the evacuation process. The maximum distance of the corridor in a hotel building is 45 meters if using a sprinkler, but at the Grand Kanaya Hotel, the maximum 
distance on floors 3 to 6 reaches 54 meters, which means it exceeds the specified standard. While for dimensions, the corridor meets the standard, which is not less than 2 meters in height and not less than 1 meter in width. The following are the conditions of the corridor at Grand Kanaya Hotel (Figure 12 and Figure 13).

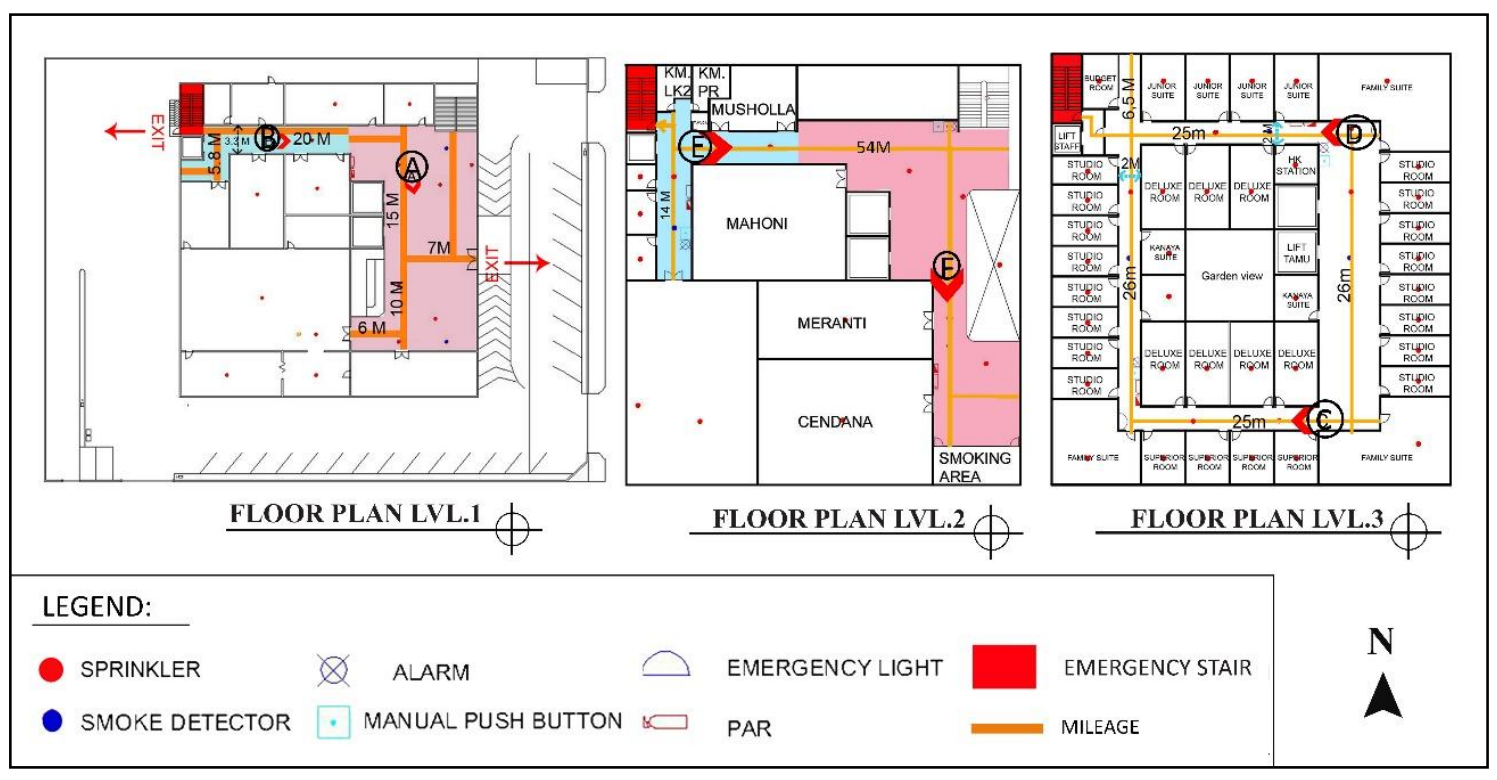

Figure 12. Grand Kanaya Hotel Corridor Plan

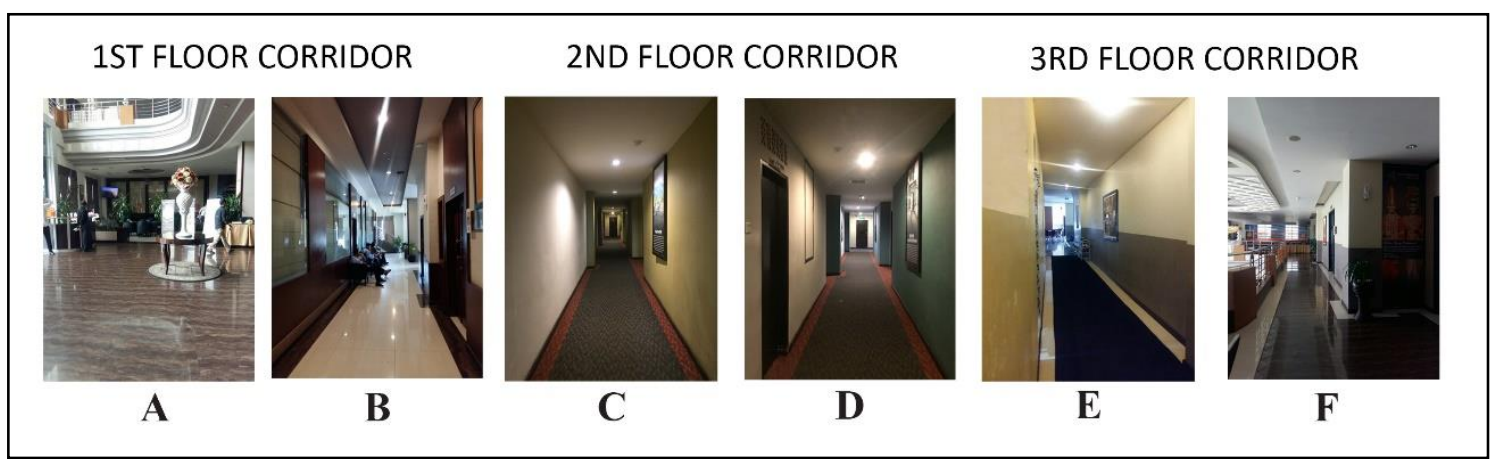

Figure 13. The Condition of Grand Kanaya Hotel Corridor

In the Grand Kanaya Hotel building, there is one emergency staircase and not according to the provisions of the emergency stairs requirements, which is at least having two emergency stairs. The emergency staircase consists of an emergency door, but the emergency door on the building uses wood material that is not fire-resistant and does not have a push/air pressure fan to provide positive pressure to prevent smoke from entering the emergency stairwell. Therefore, this condition is contrary to the standard of the emergency stairway stated in SNI 03-1746-2000 [6]. Grand Kanaya Hotel Emergency stairs are in Figure 14. 


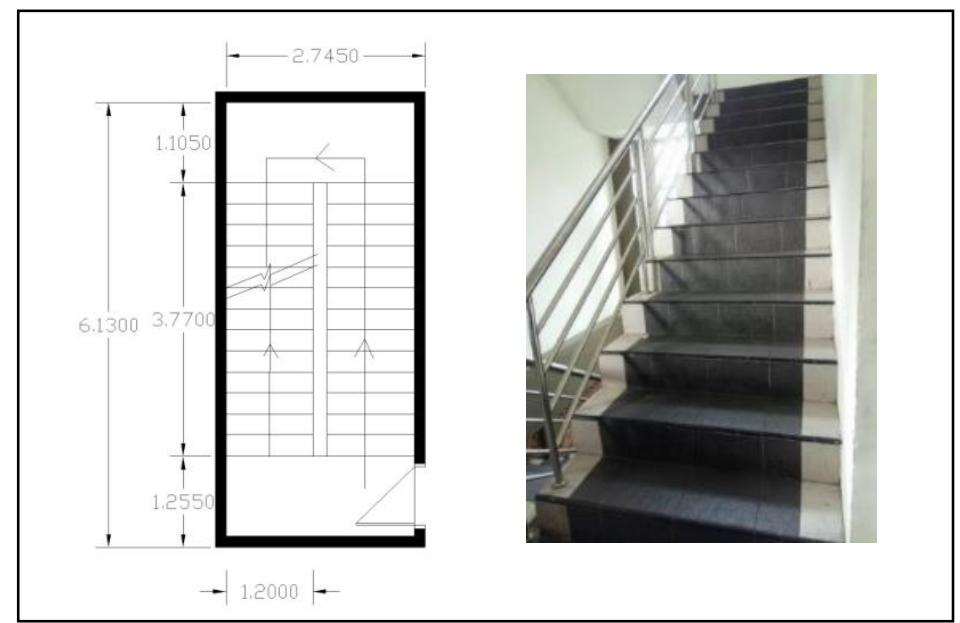

Figure 14. Grand Kanaya Hotel Emergency Staircase

The building's emergency door is $80 \mathrm{~cm}$ wide and has an "EXIT" sign above the door. The emergency door on the building has met the dimensions standard, but the emergency door contained in the Grand Kanaya Hotel building uses wood material that is not fire-resistant and is also not equipped with a driving fan to give positive pressure (Figure 15).

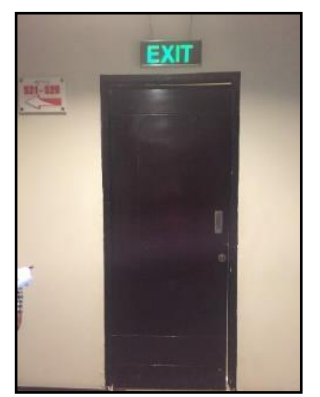

Figure 15. Grand Kanaya Hotel Emergency Door

\section{Conclusion}

In the Grand Kanaya Hotel building there are several fire protection systems that do not meet the specified standards, including, the sprinkler distance is more than $4.6 \mathrm{~m}$ with a distance of $6.6-26.8 \mathrm{~m}$, the distance between buildings in the north is $3 \mathrm{~m}$, so less from the minimum value of the inter-building distance of $6 \mathrm{~m}$, the maximum distance of the corridor on the $3 \mathrm{rd}$ to 6 th floors reaches 51 meters, which means it exceeds the maximum standard of $45 \mathrm{~m}$, the emergency staircase at the Grand Kanaya Hotel building is only available 1 emergency staircase and emergency door on the hotel building using material that is not resistant to fire.

The recommendations are by adding stairs on the southeast side, replacing the emergency door with a door that uses fire-resistant material, adding detectors, sprinklers and emergency lighting according to the fire protection system requirements. 


\section{Acknowledgment}

The study results are expected to be useful as information regarding the fire protection system in the Grand Kanaya Hotel building.

\section{REFERENCES}

[1] D. P. U. RI, Peraturan Menteri Pekerja Umum RI No.26/PRT/M/2008, Persyaratan Teknis Sistem Proteksi Kebakaran pada Bangunan Gedung dan Lingkungan, Jakarta, 2008.

[2] D. P. D. Jakarta, peraturan daerah DKI JAKARTA No.3 Tahun 1992 Penanggulangan Bahaya Kebakaran dalam Wilayah DKI Jakarta, Jakarta, 1992.

[3] F. Lawson, Hotel Motels and Condominiums (Design Planning and Maintenance), London: Architectural Press, 1976.

[4] M. Egan dan David, Concept in Building Fire Safety, Canada: John Wiley \& Sons, 1978.

[5] P. Stollard dan J. Abrahams, Fire From First Principles: A Design Guide to Building Fire Safety, London: E \& FN Spon, 1999.

[6] B. S. Nasional, SNI 03-1746-2000 Tata cara perencanaan dan pemasangan sarana jalan ke luar untuk penyelamatan terhadap bahaya kebakaran pada bangunan gedung, Jakarta: Badan Penerbit PU, 2000. 